\title{
Short- and long-term metabolic responses to diets with different protein: carbohydrate ratios in Senegalese sole (Solea senegalensis, Kaup 1858)
}

\author{
Marta Conde-Sieira ${ }^{1,2}$, Emilio Salas-Leiton ${ }^{1}$, Marta M. Duarte ${ }^{1,3}$, Nicole F. Pelusio ${ }^{1}$, José L. Soengas ${ }^{2}$ and \\ Luísa M. P. Valente ${ }^{1,3 *}$ \\ ${ }^{1}$ Centro Interdisciplinar de Investigação Marinha e Ambiental (CIIMAR/CIMAR L.A. ), Universidade de Porto, Rua dos Bragas, \\ 289, 4050-123 Porto, Portugal \\ ${ }^{2}$ Laboratorio de Fisioloxía Animal, Departamento de Bioloxía Funcional e Ciencias da Saúde, Facultade de Bioloxía, \\ Universidade de Vigo, E-36310 Vigo, Spain \\ ${ }^{3}$ Instituto de Ciências Biomédicas de Abel Salazar (ICBAS), Universidade do Porto, Rua de Jorge Viterbo Ferreira 228, \\ 4050-313 Porto, Portugal
}

(Submitted 20 October 2015 - Final revision received 21 January 2016 - Accepted 22 February 2016 - First published online 5 April 2016)

\begin{abstract}
Four isolipidic and isoenergetic diets with different protein:carbohydrate $(\mathrm{CH})$ contents (48:38, 52:34, 56:30, 60:26) were fed to juvenile Senegalese sole (22.01 (sem 0.01) g) during $104 \mathrm{~d}$. Oral glucose tolerance tests were performed at the beginning ( $4 \mathrm{~d}$ ) and at the end (104 d) of the experiment to assess the effect of the dietary treatment on glucose tolerance. Samples of blood, liver and muscle of all dietary groups were also obtained at the initial and final phases of the trial at different postprandial times $(0,1,5$ and $10 \mathrm{~h}$ after feeding) in order to analyse glucose and NEFA in plasma, and metabolites and enzyme activities involved in glycogen metabolism, glycolysis, gluconeogenesis and lipogenesis pathways in liver and muscle. The results obtained in this study suggest a good glucose tolerance in Senegalese sole. This species tolerated important amounts of $\mathrm{CH}$ in the diet without showing any deleterious signs in terms of growth or any metabolic disorders. After $104 \mathrm{~d}$ of feeding diets with an important amount of $\mathrm{CH}$ (48:38 and 52:34), the control of glycaemia was maintained and even postprandial glucose levels in plasma were (in general) lower than at the beginning of the experiment. This reasonable tolerance to glucose is also reflected by an increased use of glucose through glycolysis in liver (indicated by glucokinase activity), and the absence of changes in lipogenic potential in the same tissue (indicated by ATP citrate lyase activity). No clear changes were induced in the muscle by the dietary treatments.
\end{abstract}

Key words: Dietary carbohydrate: Glucose tolerance: Glucose metabolism: Carbohydrate utilisation: Protein sparing

The capacity of fish to metabolise carbohydrate $(\mathrm{CH})$ varies among species, and it is dependent on particular characteristics such as their feeding habits ${ }^{(1-3)}$. Herbivorous or omnivorous fish species such as tilapia (Oreochromis niloticus) or bagrid catfish (Mystus nemurus) have been reported to respond favourably to elevated levels of dietary $\mathrm{CH}$ showing propitious growth associated with an adequate enzymatic response ${ }^{(4,5)}$. Carnivorous fish species do not generally tolerate high $\mathrm{CH}$ in the diet ${ }^{(1-3)}$. However, there is some variation in this capacity ${ }^{(2)}$. Thus, some carnivorous species are able to efficiently use diets with $\mathrm{CH}$ inclusion levels about $20-30 \%$, as reported for sea bass (Dicentrarchus labrax) $^{(6,7)}$, cobia (Rachycentron canadum $)^{(8)}$ or yellow croaker (Larmichthys crocea) ${ }^{(9)}$. In contrast, other carnivorous fish species such as rainbow trout (Oncorbynchus mykiss) or Atlantic salmon (Salmo salar) indicated deleterious effects of high dietary $\mathrm{CH}$ in terms of declined growth or metabolic disorders such as hepatomegaly ${ }^{(10,11)}$, which have been associated with anomalies in glucose metabolism in these species $^{(12-14)}$. These metabolic capabilities are associated with a better tolerance to glucose in herbivorous or omnivorous species, indicated by a higher clearance rate of glucose after performing a glucose tolerance test $(\mathrm{GTT})^{(3)}$. Furthermore, the tolerance to glucose in fish is influenced by other macronutrients present in the diet such as protein or lipids ${ }^{(15,16)}$.

The metabolic utilisation of dietary $\mathrm{CH}$ in fish relies mainly on the activity of hepatic enzymes, which can be modulated by nutritional conditions ${ }^{(17)}$. The nutritional modulation of enzymes involved in glucose metabolism varies among different species, and even within single species, depending on several factors such as temperature, age or nutritional background ${ }^{(1,17)}$. Thus, increased activity of glycolitic enzymes such as glucokinase (GK), 6-phosphofructo 1-kinase and pyruvate kinase (PK) were found in the liver of different fish species such as rainbow trout, gilthead seabream (Sparus

Abbreviations: ACLY, ATP citrate lyase; CH, carbohydrate; G6Pase, glucose-6-phosphatase; GK, glucokinase; GTT, glucose tolerance test; PK, pyruvate kinase.

* Corresponding author: L. M. P. Valente, fax +351 2234018 38, email lvalente@icbas.up.pt 
aurata), common carp (Cyprinus carpio) or European sea bass (D. labrax) fed diets containing high levels of $\mathrm{CH}^{(18,19)}$. No such response was found in the muscle of carnivorous fish species ${ }^{(3,20)}$ in contrast to what is observed in omnivorous fish species ${ }^{(21)}$. Furthermore, enzymes involved in endogenous glucose production in liver are not affected by dietary $\mathrm{CH}$ content in most fish species studied ${ }^{(12,14,19)}$, whereas an inhibition of gluconeogenesis was observed in common carp and gilthead seabream ${ }^{(22)}$. Moreover, enzymes involved in hepatic lipogenesis are poorly induced by $\mathrm{CH}$ in carnivorous fish ${ }^{(23)}$. All these metabolic divergences, added to different digestive characteristics, distinguish fish capability to use dietary $\mathrm{CH}$.

The dietary $\mathrm{CH}$ utilisation in fish is of great economical and environmental importance in the present context of aquaculture nutrition, as the alternative ingredients to the marine protein sources normally used in aquafeeds are obtained from vegetable sources, which contain high levels of $\mathrm{CH}^{(2)}$. In consequence, in the past years, several strategies able to modulate hepatic enzymes, such as the use of adaptation diets, genetic selection or the application of nutritional programming, have been used to improve $\mathrm{CH}$ utilisation in fish ${ }^{(24,25)}$.

Senegalese sole (Solea senegalensis, Kaup 1858) is a flatfish with economical interest in European aquaculture ${ }^{(26)}$. It has high protein requirement ${ }^{(27)}$ and low capacity to utilise dietary lipids efficiently ${ }^{(28-30)}$. In terms of glucose tolerance, Conde-Sieira et al. ${ }^{(31)}$ have recently reported that Senegalese sole is able to develop an efficient metabolic response under induced short-term hyperglycaemia, showing a good capacity to restore glucose homoeostasis. Furthermore, previous studies carried out with diets rich in $\mathrm{CH}$ suggest a good capacity of this species to use $\mathrm{CH}$ in terms of nutrient retention and growth potential ${ }^{(29,32)}$ (Salas-Leiton et al., unpublished results). In a way similar to that observed in mammals and other fish species, glucose tolerance in Senegalese sole is impaired if fish are fed fat-enriched diets, resulting in prolonged hyperglycaemia and impaired insulin signalling ${ }^{(15,16)}$. Accordingly, Borges et al. ${ }^{(16)}$ recommended a low lipid dietary inclusion to improve $\mathrm{CH}$ utilisation in this species, in contrast to the common aquaculture practices in which the use of fatty diets is usual for fish culture.

Taking all of this into account, this study aimed to evaluate in Senegalese sole the metabolic effect of feeding low-lipid diets with increasing protein: $\mathrm{CH}$ ratio at short- and long-term. The postprandial modulation of enzyme activities mainly related to glucose metabolism in liver and muscle, at short- and long-term, as well as the possible metabolic adaptation to dietary $\mathrm{CH}$ after a relatively long period of feeding $\mathrm{CH}$-enriched diets were particularly focused. GTT were performed in fish 4 and $104 \mathrm{~d}$ after feeding four experimental diets containing increasing protein: $\mathrm{CH}$ content. In addition, the levels of metabolites in plasma (glucose, NEFA) and liver (glucose, glycogen, NEFA) were measured. Hepatic enzyme activities involved in glycolysis, glycogen metabolism, gluconeogenesis and lipogenesis were determined in the various dietary treatments. In muscle, both metabolite levels (glucose, glycogen, TAG) and hexokinase (HK) and glycogen phosphorylase (GPase) enzyme activities were assessed.

\section{Methods}

The experiments described comply with the Guidelines of the European Union Council on protection of animals (2010/63/ EU) and were supervised by trained scientists following the Federation of European Laboratory Animal Science Associations category $\mathrm{C}$ recommendations.

\section{Experimental diets}

The experimental diets were isoenergetic $(21 \mathrm{~kJ} / \mathrm{g} D M)$, isolipidic (6\% DM) and contained four different dietary crude protein:total $\mathrm{CH}$ ratios: 48:38, 52:34, 56:30 and 60:26. The formulation and proximate composition of diets (Sparos) are presented in Table 1.

Diet composition analysis was carried out in duplicate following the methodology described by the Association of Official Analytical Chemists (AOAC) ${ }^{(33)}$. Ash was analysed by combustion $\left(550^{\circ} \mathrm{C}\right.$ during $6 \mathrm{~h}$ ) in a muffle furnace (Nabertherm L9/11/B170) and crude protein $(\mathrm{N} \times 6.25)$ using a Leco $\mathrm{N}$ analyser (model FP-528; Leco Corporation). Crude lipid content was determined by petroleum ether extraction $\left(40-60^{\circ} \mathrm{C}\right)$ using a Soxtec ${ }^{\mathrm{TM}} 2055$ Fat Extraction System (Foss), whereas starch followed Thivend et al. ${ }^{(34)}$. Gross energy was quantified in an adiabatic bomb calorimeter (Werke C 2000 basic; IKA).

\section{Fish and rearing conditions}

Senegalese sole juveniles were obtained from a fish farm (Aquácria Piscícolas, S.A.) where they were fed a commercial diet (9\% CH, 16\% lipids; $62 \%$ crude protein), and transported to the experimental facilities of CIIMAR, Porto, Portugal where the growth trial was conducted. After arrival at the experimental unit, fish were kept under quarantine conditions for a 2-week period. Once acclimated to the new rearing facilities, 22 fish (22.01 (SEM 0.01) g)/dietary condition were individually weighed, measured and distributed (initial stocking density of $1.65 \mathrm{~kg} / \mathrm{m}^{2}$ ) among twelve fibreglass rectangular tanks $(0.5 \mathrm{~m} \times 0.4 \mathrm{~m})$ in a closed recirculation system. The system was supplied with filtered and heated $\left(20.0(\operatorname{SEM} 1.0)^{\circ} \mathrm{C}\right)$ saltwater $(24 \%$ ) at a flow rate of $1.5 \mathrm{l} / \mathrm{min}$. Total ammonium, nitrite, nitrate and $\mathrm{pH}$ levels were measured during the entire trial to ensure levels within the recommended ranges for marine species. Dissolved oxygen level was kept above $90 \cdot 0 \% \pm 1.0$ saturation. An artificial photoperiod of $12 \mathrm{~h}$ light $-12 \mathrm{~h}$ dark was established. Triplicate groups of fish were fed to satiety with each dietary treatment using automatic feeders that distributed 8-10 meals/d during $104 \mathrm{~d}$. The meal size offered to each tank was daily adjusted according to observations by an experienced researcher and based on the previous presence/absence of uneaten feed in each $\operatorname{tank}^{(28,35)}$. By the end of the feeding trial and after the 24-h fasting period, soles were individually weighed $(\mathrm{g})$ and measured (total length, cm). Daily Growth Index (DGI) was calculated as follows: $100 \times\left(\left(\mathrm{W}_{1}\right)^{1 / 3}-\left(\mathrm{W}_{0}\right)^{1 / 3}\right) / \mathrm{d}$, where $\mathrm{W}_{0}$ and $\mathrm{W}_{1}$ are the initial and the final fish mean weights $(\mathrm{g})$. Feed conversion ratio (FCR) was calculated as the amount of dry food intake (g)/weight gain (g). Voluntary feed intake (VFI) (g or $\mathrm{kJ} / \mathrm{kg}$ average body weight (ABW) per $\mathrm{d}$ ) was calculated as cumulative 
Table 1. Ingredients and proximate composition of the experimental diets

\begin{tabular}{|c|c|c|c|c|}
\hline & \multicolumn{4}{|c|}{ Dietary treatments } \\
\hline & 48:38 & $52: 34$ & $56: 30$ & $60: 26$ \\
\hline \multicolumn{5}{|l|}{ Feed ingredients (\%) } \\
\hline Fishmeal 70 LT (Norvik) ${ }^{\star}$ & $40 \cdot 0$ & $40 \cdot 0$ & $40 \cdot 0$ & $40 \cdot 0$ \\
\hline Squid meal† & $6 \cdot 0$ & $6 \cdot 0$ & $6 \cdot 0$ & $6 \cdot 0$ \\
\hline Wheat gluten $\ddagger$ & 3.5 & 9.5 & $15 \cdot 5$ & $22 \cdot 0$ \\
\hline Wheat meal§ & 23.5 & 20.5 & $16 \cdot 0$ & $12 \cdot 0$ \\
\hline Peas gelatinised (Aquatex 8071)\| & $25 \cdot 0$ & $22 \cdot 0$ & $20 \cdot 5$ & $18 \cdot 0$ \\
\hline Vitamin and mineral Premix PV01ף & 1.0 & 1.0 & $1 \cdot 0$ & 1.0 \\
\hline Choline chloride ${ }^{\star *}$ & 0.2 & 0.2 & 0.2 & 0.2 \\
\hline Betaine $\mathrm{HCl}+\dagger$ & 0.3 & 0.3 & 0.3 & 0.3 \\
\hline 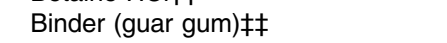 & 0.3 & 0.3 & 0.3 & 0.3 \\
\hline Antioxidant powder (Paramega)§§ & 0.2 & 0.2 & 0.2 & 0.2 \\
\hline \multicolumn{5}{|l|}{ Proximate composition } \\
\hline DM (\%) & $95 \cdot 7$ & $94 \cdot 4$ & 94.4 & $94 \cdot 7$ \\
\hline Ash (\% DM) & $7 \cdot 8$ & $7 \cdot 7$ & 7.5 & 7.5 \\
\hline $\mathrm{CP}(\% \mathrm{DM})$ & $48 \cdot 2$ & $51 \cdot 6$ & $56 \cdot 3$ & $59 \cdot 7$ \\
\hline CF $(\%$ DM) & $6 \cdot 4$ & 6.5 & $6 \cdot 4$ & $6 \cdot 3$ \\
\hline Starch (\% DM) & $26 \cdot 7$ & 23.6 & $20 \cdot 8$ & $17 \cdot 7$ \\
\hline Total carbohydrate (\% DM)||II & 37.6 & $34 \cdot 3$ & $29 \cdot 8$ & $26 \cdot 5$ \\
\hline Gross energy (kJ/g DM) & $20 \cdot 2$ & 20.6 & $20 \cdot 8$ & $21 \cdot 2$ \\
\hline
\end{tabular}

$\mathrm{CP}$, crude protein; CF, crude fat.

* Danish fishmeal LT70: $71 \%$ crude protein (CP), $11 \%$ crude fat (CF) (Sopropêche).

† Super prime without guts: $84 \%$ CP, $4.7 \%$ CF (Sopropêche).

‡ Vital: $84 \%$ CP, $1.3 \%$ CF (Roquette)

§ Whole wheat: $10.2 \%$ CP, $1.2 \%$ CF (Casa Lanchinha).

II Dehulled, microgrinded and extruded pea meal: $24 \%$ CP, $0.4 \%$ CF (Sotexpro).

II Vitamins (IU or $\mathrm{mg} / \mathrm{kg}$ diet): DL- $\alpha$-tocopheryl acetate, $100 \mathrm{mg}$; sodium menadione bisulphate, $25 \mathrm{mg}$; retinyl acetate, $20000 \mathrm{IU}$; DL-cholecalciferol, $2000 \mathrm{IU}$; thiamin, $30 \mathrm{mg}$; riboflavin, $30 \mathrm{mg}$; pyridoxine, $20 \mathrm{mg}$; cyanocobalamin, $0.1 \mathrm{mg}$; nicotinic acid, $200 \mathrm{mg}$; folic acid, $15 \mathrm{mg}$; ascorbic acid, $1000 \mathrm{mg}$; inositol, $500 \mathrm{mg}$; biotin, $3 \mathrm{mg}$; calcium panthotenate, $100 \mathrm{mg}$; minerals (g or mg/kg diet): cobalt carbonate, $0.65 \mathrm{mg}$; copper sulphate, $9 \mathrm{mg}$; ferric sulphate, $6 \mathrm{mg}$; potassium iodide, $0.5 \mathrm{mg}$; manganese oxide, $9.6 \mathrm{mg}$; sodium selenite, $0.01 \mathrm{mg}$; zinc sulphate, $7.5 \mathrm{mg}$; sodium chloride, $400 \mathrm{mg}$; calcium carbonate, $1.86 \mathrm{~g}$; excipient wheat middlings (Premix Lda).

** Choline chloride $60 \%$ (Premix Lda).

†† Betaine $\mathrm{HCl} 98 \%$ (Premix Lda).

拉 Guar gum HV109 (Seah International).

$\S \S$ Paramega PX (Kemin Europe NV).

IIII Estimated by difference $(100-$ ash $-\mathrm{CP}-\mathrm{CF})$.

dry feed consumption/ABW per $\mathrm{d}$, where ABW (kg) was $\left(\mathrm{W}_{1}+\mathrm{W}_{0}\right) / 2$. The retention (\% intake) was calculated as follows: $100 \times\left(\mathrm{W}_{1} \times\right.$ final carcass nutrient or energy content $\mathrm{W}_{0} \times$ initial carcass nutrient or energy content)/total nutrient or energy intake (g or kJ/kg ABW per day).

\section{Glucose tolerance test}

GTT were performed at the initial and the final phases of the experiment ( 4 and $104 \mathrm{~d}$ after the beginning of the growth trial, respectively). With this purpose, thirty-two fish per dietary condition were distributed among eight tanks (two tanks/ dietary condition) and maintained in the same conditions as described above. Senegalese sole fasted for $24 \mathrm{~h}$ were anaesthetised with MS-222 (100 mg/l) and immediately weighed (mean weight 25.76 (SEM 0.47) g at the initial phase and 56.79 (SEM $1.15) \mathrm{g}$ at the final phase) for oral administration of $10 \mathrm{ml} / \mathrm{kg}$ fish of a saline solution with $1 \mathrm{~g} / \mathrm{kg}$ of D-glucose. This concentration was selected according to previous studies ${ }^{(36)}$ and successfully used also in Senegalese sole ${ }^{(31)}$. After oral administration, fish were placed in individual tanks according to different diets and sampling times (one tank per diet and per sampling point). Before glucose administration and after 1, 5 and $10 \mathrm{~h}$, eight fish per dietary treatment were removed from the corresponding tank, anesthetised as above and blood sampled by caudal puncture with ammonium-heparinised syringes. Plasma samples were obtained after blood centrifugation, followed by deproteinisation with $0.6 \mathrm{~m}$-perchloric acid and neutralisation with $1 \mathrm{~m}$-potassium bicarbonate, frozen on dry ice and stored at $-80^{\circ} \mathrm{C}$ until further assay of glucose.

\section{Postprandial metabolic sampling}

Both at the initial ( $4 \mathrm{~d}$ after the beginning of the growth trial) and at the final phases (104d) of the experiment, tissue samples of fish from all experimental diets were taken at different postprandial times in order to analyse metabolic parameters. Thus, eight fish of each experimental diet were fed once to satiety and sampled just before feeding and 1, 5 and $10 \mathrm{~h}$ after the single meal distribution. On each sampling time, fish were removed from holding tanks, anaesthetised as above, and weighed. At each postprandial sampling time, all fish were sampled from a single tank (T0 and T10 from the same tank) to avoid the stress induced by fish manipulation from one sampling to the following one. Blood was collected by caudal puncture with ammonium-heparinised syringes. Plasma samples were obtained and processed as described above. Fish were killed rapidly by decapitation and liver and muscle were removed, weighed, frozen in dry ice and stored at $-80^{\circ} \mathrm{C}$ until assayed. 


\section{Assessment of metabolite levels and enzyme activities}

Plasma glucose levels were quantified by using a commercial kit (Biomérieux) adapted to a microplate format. Metabolite levels were assessed in $75 \mathrm{mg}$ of liver and $150 \mathrm{mg}$ of muscle homogenised immediately by ultrasonic disruption with 5.5 vols (liver) or 3.5 vols (muscle) of ice-cooled $0.6 \mathrm{~m}$-perchloric acid, and neutralised (using $1 \mathrm{~m}$-potassium bicarbonate). The homogenate was centrifuged (10000 $\mathrm{g}, 4 \mathrm{~min})$, and the resulting supernatant was immediately frozen in dry ice and stored at $-80^{\circ} \mathrm{C}$ until analysis. Liver and muscle glycogen levels were assessed using the method of Keppler \& Decker ${ }^{(37)}$, and glucose obtained after glycogen breakdown (after subtracting free glucose levels) was determined with a commercial kit (Biomérieux). TAG levels in muscle and NEFA levels in plasma and liver were also analysed with commercial kits (Spinreact and Wako, respectively).

The activities of enzymes involved in glycolysis (GK and PK), glycogen metabolism (glycogen synthase (GSase) and GPase), gluconeogenesis (glucose-6-phosphatase (G6Pase), fructose-1,6-biphosphatase (FBPase) and phosphoenolpyruvate carboxykinase (PEPCK)) and lipogenesis (glucose-6-phosphate dehydrogenase (G6PDH), ATP citrate lyase (ACLY)) were determined in the various dietary treatments. Enzyme activities were assessed in $150 \mathrm{mg}$ of liver and $250 \mathrm{mg}$ of muscle samples homogenised by ultrasonic disruption with 7 vols (liver) or 4 vols (muscle) of ice-cold buffer consisting of $50 \mathrm{~mm}$-Tris (pH 7.6), 5 mm-EDTA, 2 mm-1,4-dithiothreitol and a protease inhibitor cocktail (Sigma Chemical Co.). The homogenate was centrifuged $(900 \mathrm{~g}, 10 \mathrm{~min})$ and the supernatant was immediately frozen on dry ice and stored at $-80^{\circ} \mathrm{C}$ until analysis. Enzyme activities were determined in a microplate reader SPECTRAFluor (Tecan). Reaction rates of enzymes were determined by the increase or decrease in absorbance of NAD $(\mathrm{P}) \mathrm{H}$ at $340 \mathrm{~nm}$. The reactions were started by the addition of homogenates $(10-15 \mu \mathrm{l})$, at a pre-established protein concentration, omitting the substrate in control wells (final volume $265-295 \mu \mathrm{l}$ ), and allowing the reactions to proceed at $37^{\circ} \mathrm{C}$ for pre-established times $(5-45 \mathrm{~min})$. Enzymatic analyses were carried out at maximum rates, with the reaction mixtures set up in preliminary tests to render optimal activities by adapting to Senegalese sole methods previously described for rainbow trout ${ }^{(31,36)}$. An unit of enzyme activity (U) is defined as the amount of enzyme that catalysed the hydrolysis of $1 \mu \mathrm{mol}$ of substrate/min, and the activity was normalised by milligrams of soluble protein. Protein was assayed in triplicate in homogenates using microplates according to the bicinchoninic acid $\operatorname{method}^{(38)}$ using bovine serum albumin (Sigma) as standard.

\section{Statistical analysis}

All results are expressed as mean values with their standard errors. Statistical differences were assessed with a three-way ANOVA, with diet (48:38, 52:34, 56:30 or 60:26), time (0, 1, 5 and $10 \mathrm{~h}$ ) and phase (initial and final) as main factors. Only in those cases in which a significant effect was noted within a factor, post hoc comparisons were carried out by a Student-Newman-Keuls test, and differences were considered statistically significant at $P<0.05$. When necessary, data were log-transformed to fulfil the conditions of the ANOVA. In the case of growth parameters and feed intake, statistical analyses were performed by one-way ANOVA with dietary treatment as the main factor.

\section{Results}

Fish mortality was $\leq 1 \%$ in all experimental treatments. All groups exhibited around a $2 \cdot 5$-fold increase in their initial body weight (22.0 g) after the 15-week experimental period (Table 2). No significant differences related to DGI were observed among dietary treatments (range of 0.9-1.0). The Hepatosomatic Index (HSI) was also similar among fish (0.9-1·1). A significant decrease in FCR values was observed in sole fed diets with increasing protein (values ranging from 1.5 to 1.2 in $48: 38$ and 60:26 diets, respectively). VFI decreased significantly when dietary $\mathrm{CH}$ was progressively substituted by protein.

Table 2. Growth performance parameters and feed intake of Senegalese sole fed the experimental diets for $104 \mathrm{~d}$ (Mean values with their standard errors; $n$ )

\begin{tabular}{|c|c|c|c|c|c|c|c|c|}
\hline & \multicolumn{8}{|c|}{ Dietary treatments } \\
\hline & \multicolumn{2}{|c|}{$48: 38$} & \multicolumn{2}{|c|}{$52: 34$} & \multicolumn{2}{|c|}{$56: 30$} & \multicolumn{2}{|c|}{$60: 26$} \\
\hline & Mean & SEM & Mean & SEM & Mean & SEM & Mean & SEM \\
\hline $\mathrm{HSI}$ & 1.05 & 0.12 & 0.85 & 0.00 & 0.93 & 0.00 & 0.95 & 0.06 \\
\hline \multicolumn{9}{|l|}{ Growth } \\
\hline Final body weight $(\mathrm{g})$ & $54 \cdot 50$ & 1.62 & $58 \cdot 46$ & 1.33 & $56 \cdot 24$ & 0.98 & $54 \cdot 42$ & 1.44 \\
\hline DGI & 0.95 & 0.06 & 1.04 & 0.00 & 0.99 & 0.00 & 0.95 & 0.06 \\
\hline FCR & $1.52^{\mathrm{a}}$ & 0.00 & $1.26^{\mathrm{b}}$ & 0.00 & $1.17^{\mathrm{b}, \mathrm{c}}$ & 0.00 & $1 \cdot 15^{\mathrm{c}}$ & 0.06 \\
\hline VFI (g/kg ABW per d) & $12 \cdot 56^{\mathrm{a}}$ & 0.12 & $11.01^{\mathrm{b}}$ & 0.17 & $9.81^{\mathrm{c}}$ & 0.12 & $9 \cdot 39^{\mathrm{C}}$ & 0.12 \\
\hline \multicolumn{9}{|l|}{ Retention (\% intake) } \\
\hline DM & $16 \cdot 44^{\mathrm{b}}$ & $1 \cdot 0$ & $20 \cdot 09^{a}$ & 0.8 & $20 \cdot 87^{a}$ & 0.6 & $21 \cdot 72^{\mathrm{a}}$ & 1.7 \\
\hline Protein & $24 \cdot 18^{\mathrm{b}}$ & 1.7 & $28 \cdot 81^{a}$ & 1.6 & $27 \cdot 50^{\mathrm{a}, \mathrm{b}}$ & 1.3 & $27 \cdot 21^{a, b}$ & 1.8 \\
\hline Energy & $19 \cdot 26^{b}$ & $1 \cdot 1$ & $23 \cdot 25^{\mathrm{a}}$ & 1.9 & $23 \cdot 81^{\mathrm{a}}$ & 1.0 & $24.79^{a}$ & 1.7 \\
\hline
\end{tabular}

HSI, Hepatosomatic Index: liver weight (g)/body weight $(\mathrm{g})$; DGI, Daily Growth Index: $100 \times\left(\left(\mathrm{W}_{1}\right)^{1 / 3}-\left(\mathrm{W}_{0}\right)^{1 / 3}\right) / \mathrm{d}$, where $\mathrm{W}_{0}$ and $\mathrm{W}_{1}$ are the initial and the final fish mean weights $(\mathrm{g})$; FCR, feed conversion ratio: dry food intake $(\mathrm{g}) /$ weight gain $(\mathrm{g})$; VFI, voluntary feed intake: cumulative dry feed consumption/average body weight $(\mathrm{ABW})$ per $\mathrm{d}$, where $\mathrm{ABW}(\mathrm{kg})$ was $\left(\mathrm{W}_{1}+\mathrm{W}_{0}\right) / 2$. a,b,c Mean values with unlike superscript letters were significantly different $(P<0.05)$ between dietary conditions. 
As a consequence, lipid, $\mathrm{CH}$ and energy intake followed the same trend. The lowest DM and energy retention was obtained for fish fed the 48:38 diet, as a result of increased DM intake. Sole fed the 52:34 diet showed significantly higher protein retention than those fed the 48:38 diet (Table 2).

The statistical significance of the differences observed in GTT and the metabolic parameters assessed in plasma, liver and muscle, attributed to main factors in three-way ANOVA, are shown in Table 3. The significant differences resulting from post hoc comparisons are detailed in each figure (Figs. 2-8). Significant differences of Fig. 1 are detailed in an annexed table in the online Supplementary material.

GTT results (Fig. 1) indicate no changes among diets at the initial phase of the experiment. Increments of plasma glucose levels were observed at $\mathrm{T} 1$ and $\mathrm{T} 5$, although they were not significantly different from basal levels. These increased levels were totally recovered at $10 \mathrm{~h}$ in all dietary groups. At the end of the experiment, GTT also showed higher increments of glucose at T1 and T5 with total recovery of basal levels at T10, except in fish fed the 60:26 diet that had significantly higher values than those fed 52:34 and 48:38 diets.

As for metabolite levels in plasma (Fig. 2), increments of glucose levels at the initial phase of the trial were observed 1 and $10 \mathrm{~h}$ after feeding diets with high $\mathrm{CH}$ content (48:38 and 52:34). At the end of the experiment, postprandial increments of plasma glucose levels were observed in all groups except 56:30, and, in general, glucose levels were lower at this phase than at the beginning. Values obtained for plasma NEFA levels tended to decrease postprandially (more clearly in $48: 38$ and 56:30), whereas increased levels were observed in 60:26 at the final phase.
In liver, glycogen values (Fig. 3) were in general higher in fish fed $\mathrm{CH}$-enriched diets at the initial phase of the experiment, whereas at the end of the experiment glycogen levels did not respond to dietary treatment and showed lower values than at the initial phase. Postprandial NEFA levels tended to increase after feeding low protein: $\mathrm{CH}$ diets and to decrease in fish fed with high protein:CH diets. Thus, lower NEFA levels were observed in fish fed the 48:38 diet than those fed the 60:26 diet, both at T0 and T5, whereas the opposite was observed at T10. At the final phase of the experiment, levels of hepatic NEFA were lower than in the beginning.

An increased postprandial glycolitic potential indicated by GK and PK activities in liver (Fig. 4) was observed in fish fed all diets at the beginning of the experiment. In the final phase, increased postprandial values were observed in fish fed $\mathrm{CH}-$ enriched diets at different times: the 48:38 group presented higher GK activity at T10 than at T0, whereas the 52:34 group showed higher GK activity at T1 than at T0 and T10; PK activity was also higher at T5 compared with T0 in the 48:38 dietary group. However, these postprandial increments were not observed in fish fed a lower dietary $\mathrm{CH}$ content (56:30 and 60:26). Moreover, basal levels (T0) in these dietary groups (56:30 and 60:26) were higher than those presented by diets with a high $\mathrm{CH}$ content (48:38). Postprandial GPase activity decreased in the 48:38 diet compared with basal levels at T5 and T10 and GSase responded to CH content in 48:38 and 60:26 diets at the final but not at the initial phase of the experiment (Fig. 4). The postprandial gluconeogenic activity in liver (Fig. 5), indicated by the activities of FBPase, G6Pase and PEPCK, tended to decrease in the 48:38 group at the beginning of the

Table 3. $P$-values obtained after three-way ANOVA of parameters assessed in Senegalese sole. Diet (48:38, 52:34, 56:30 or 60:26), time (0, 1, 5, and 10 h) and phase (initial and final) were the main factors. Diet $\times$ time, diet $\times$ phase and time $\times$ phase are the first-order interactions. Diet $\times$ time $\times$ phase is the second-order interaction*

\begin{tabular}{|c|c|c|c|c|c|c|c|}
\hline Parameters & Diet & Time & Phase & Diet $\times$ time & Diet $\times$ phase & Time $\times$ phase & Diet $\times$ time $\times$ phase \\
\hline Glucose tolerance test & - & $<0.001$ & 0.035 & - & - & $<0.001$ & - \\
\hline \multicolumn{8}{|l|}{ Plasma } \\
\hline Glucose levels & 0.019 & 0.004 & $<0.001$ & - & $<0.001$ & - & 0.021 \\
\hline NEFA levels & 0.017 & 0.001 & $<0.001$ & - & - & 0.002 & - \\
\hline \multicolumn{8}{|l|}{ Liver } \\
\hline Glucose levels & - & 0.006 & 0.005 & 0.004 & 0.002 & - & - \\
\hline Glycogen levels & - & - & $<0.001$ & - & $<0.001$ & 0.004 & 0.028 \\
\hline NEFA levels & - & - & $<0.001$ & 0.008 & - & - & 0.008 \\
\hline GK activity & - & - & $<0.001$ & 0.011 & - & $<0.001$ & - \\
\hline PK activity & - & - & 0.003 & - & - & 0.005 & 0.008 \\
\hline GPase activity & - & $<0.001$ & $<0.001$ & - & - & - & - \\
\hline GSase activity & 0.038 & - & 0.004 & - & - & - & $<0.001$ \\
\hline FBPase activity & - & - & - & - & - & - & - \\
\hline G6Pase activity & 0.036 & - & 0.028 & - & - & 0.007 & - \\
\hline PEPCK activity & - & - & - & - & - & - & 0.035 \\
\hline G6PDH activity & - & - & $<0.001$ & - & - & - & - \\
\hline ACLY activity & $<0.001$ & 0.046 & $<0.001$ & - & - & - & - \\
\hline \multicolumn{8}{|l|}{ Muscle } \\
\hline Glucose levels & - & 0.004 & - & 0.007 & - & - & 0.004 \\
\hline Glycogen levels & 0.005 & - & - & 0.039 & - & - & 0.008 \\
\hline TAG & - & 0.039 & $<0.001$ & - & - & $<0.001$ & 0.009 \\
\hline HK activity & - & - & $<0.001$ & 0.004 & - & 0.023 & - \\
\hline GSase activity & 0.008 & - & 0.002 & - & - & - & - \\
\hline
\end{tabular}

GK, glucokinase; PK, pyruvate kinase; GPase, glycogen phosphorylase; GSase, glycogen synthase; FBPase, fructose-1,6-biphosphatase; G6Pase, glucose-6-phosphatase; PEPCK, phosphoenolpyruvate carboxykinase; G6PDH, glucose-6-phosphate dehydrogenase; ACLY, ATP citrate lyase; HK, hexokinase.

${ }^{*}$ All values are significantly different unless noted by a dash. 

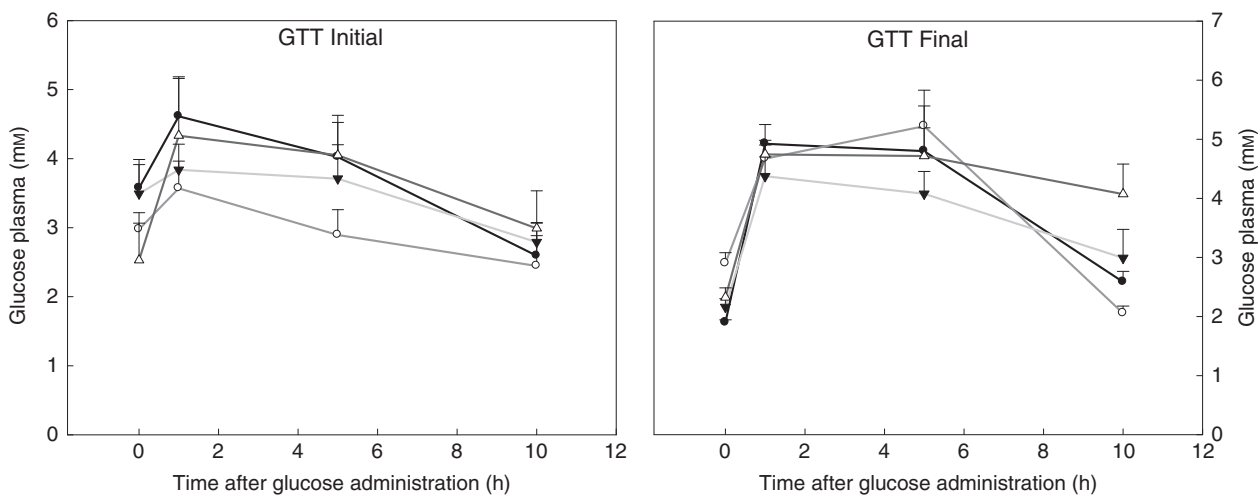

Fig. 1. Glucose levels in plasma after oral administration of $10 \mathrm{ml} / \mathrm{kg}$ of saline solution with glucose $(1 \mathrm{~g} / \mathrm{kg})$ sampled $0,1,5$ and $10 \mathrm{~h}$ after administration performed at the initial $(4 \mathrm{~d})$ or final $(104 \mathrm{~d})$ phase of the trial with four different protein:carbohydrate ratio diets $(-\longrightarrow, 48: 38 ;-0-, 52: 34 ; \square-, 56: 30$ or $\rightarrow-, 60: 26)$. Values are means ( $n 8$ fish per diet and postprandial time), with standard errors. Statistical differences $(P<0.05)$ are indicated in the annexed tables in the online Supplementary material. GTT, glucose tolerance test.
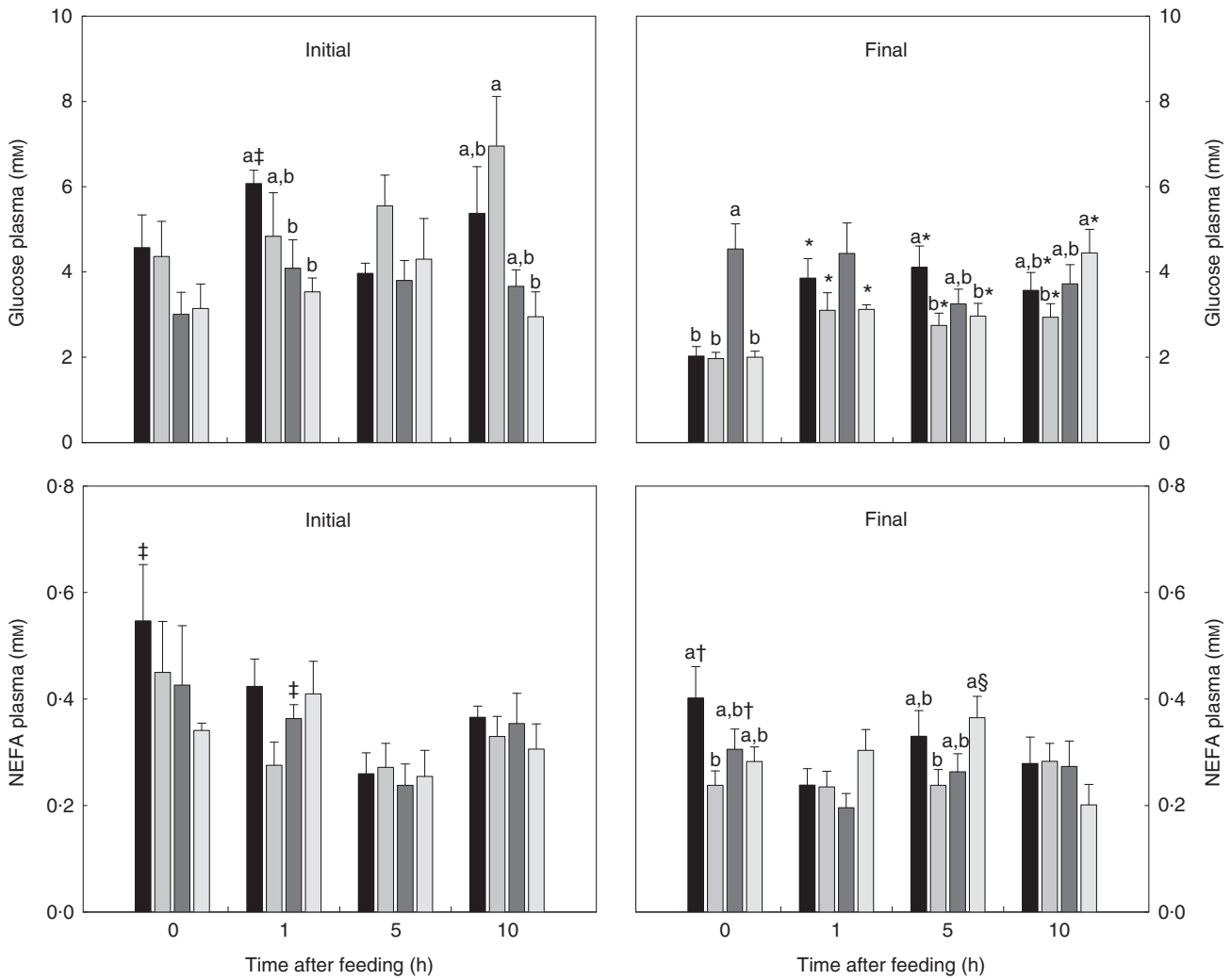

Fig. 2. Glucose and NEFA levels in plasma at different postprandial times $(0,1,5$ or $10 \mathrm{~h})$ after feeding four experimental diets $(\square, 48: 38 ; \square, 52: 34 ; \square, 56: 30$ or $\square, 60: 26$ ) with different protein:carbohydrate ratios during $4 \mathrm{~d}$ (initial) or $104 \mathrm{~d}$ (final). Values are means ( 8 fish per diet and postprandial time), with standard errors. ${ }_{a, b}$ Mean values within a column with unlike letters were significantly different $(P<0.05)$ between dietary treatments. Symbols indicate differences $(P<0.05)$ between postprandial times: * different from T0; † different from $\mathrm{T} 1 ; \ddagger$ different from $\mathrm{T} 5$ and $\S$ different from T10.

experiment, but after $104 \mathrm{~d}$ of treatment an increased gluconeogenic potential was observed. In general, lower values of G6Pase activity were observed at the final phase of the experiment compared with the initial levels. Enzymes related to the lipogenic pathway, such as G6PDH, showed higher activity in 48:38 than 60:26 dietary treatment; the opposite trend was observed for ACLY, which in addition presented lower values at the final than at the initial phase of the experiment. However,
G6PDH activity tended to be higher at the final than at the initial phase of the experiment (Fig. 6).

In muscle, increases in glucose levels were observed in the different dietary groups at different postprandial times at the initial phase of the experiment, but higher glucose and glycogen levels were obtained in fish fed diets with less $\mathrm{CH}$ content in the final phase (Fig. 7). TAG levels showed postprandial increments in 48:38 and 56:30 dietary groups at the initial, but not at the final, 

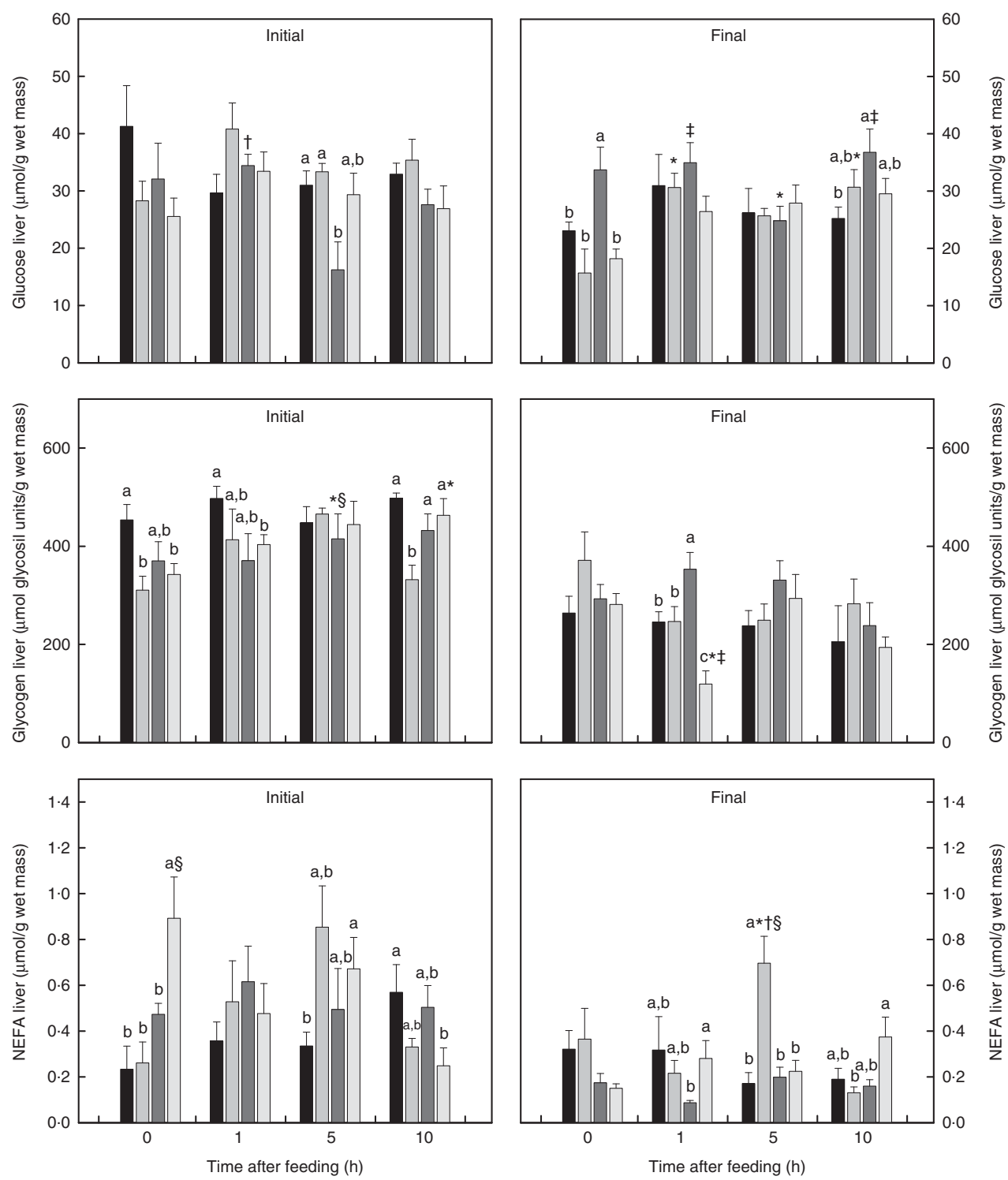

Fig. 3. Glucose, glycogen and NEFA levels in liver at different postprandial times $(0,1,5$ or $10 \mathrm{~h})$ after feeding four experimental diets ( $\square, 48: 38$; $\square, 52: 34 ; \square, 56: 30$ or $\square, 60: 26$ ) with different protein:carbohydrate ratios during $4 \mathrm{~d}$ (initial) or $104 \mathrm{~d}$ (final). Further details are indicated in Fig. 2 legend.

phase. Moreover, TAG values were generally lower at the final phase than at the initial one. An increased postprandial glycolitic potential (indicated by HK activity), as well as higher GSase activity, was observed specially in groups fed $\mathrm{CH}$-enriched diets for an extended time (Fig. 8).

\section{Discussion}

The use of $\mathrm{CH}$ in aquafeeds is of increased interest, as the replacement of marine protein sources by vegetable ones and the reduction of protein use as the main ingredient are desirable goals in current aquaculture ${ }^{(2,39)}$. However, fish present divergent capacity to utilise dietary $\mathrm{CH}$, and in some cases, especially in carnivorous species, this capacity is not adequate because of anomalies in glucose metabolism ${ }^{(3)}$. Senegalese sole seems to possess a good ability to deal with glucose loads ${ }^{(31)}$, but this capacity can be influenced by the presence of other dietary macronutrients such as lipids ${ }^{(16)}$. In the present study, feeding Senegalese sole with low-fat diets of increased protein: $\mathrm{CH}$ ratio had no effect on final body weight and daily growth rate, confirming previous studies in this species ${ }^{(32,40)}$. In contrast, other carnivorous fish species such as rainbow trout, brown trout (Salmo trutta) and Atlantic salmon showed reduced growth with the use of low protein: $\mathrm{CH}$ ratios in diet ${ }^{(11,41,42)}$. Furthermore, all fish had similar HSI, and no deleterious healthy effects were detected in the present study, even considering the extended experimental time (104d) and the elevated content of $\mathrm{CH}$ used on the tested diets (up to $38 \% \mathrm{DM}$ ). This is in contrast with previous studies in other carnivorous fish species in which high HSI levels or liver hypertrophy were observed after using elevated contents of $\mathrm{CH}$ in the diet ${ }^{(43)}$. 

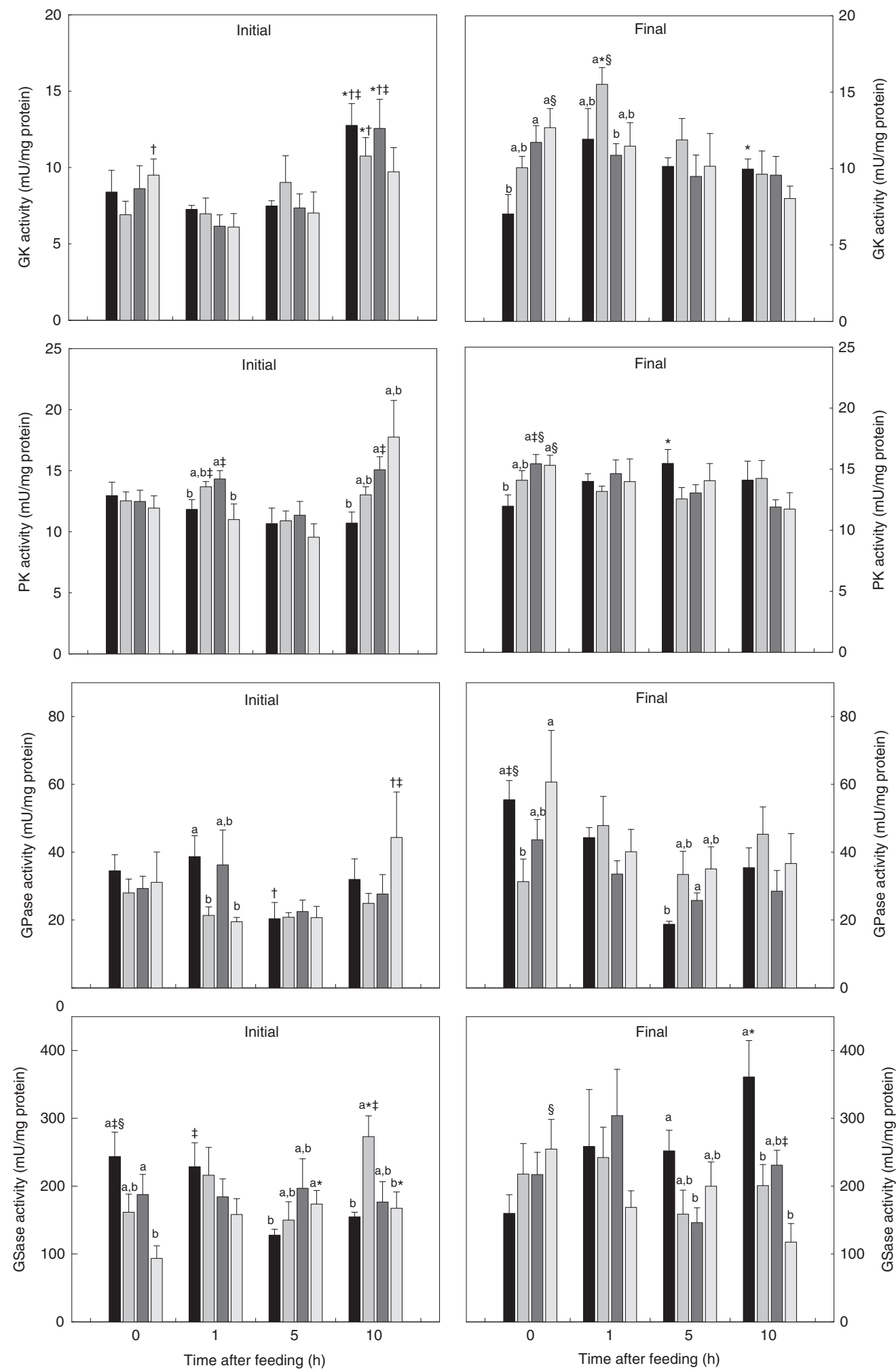

Fig. 4. Enzyme activity (mU/mg protein) related to glycolisis and glycogen metabolism in liver. Glucokinase (GK), pyruvate kinase (PK), glycogen phosphorylase (GPase) and glycogen synthase (GSase) activity at different posprandial times (0,1,5 or $10 \mathrm{~h}$ ) after feeding four experimental diets ( $\square$, 48:38; $\square, 52: 34$; $\square, 56: 30$ or $\square, 60: 26$ ) with different protein:carbohydrate ratios during $4 \mathrm{~d}$ (initial) or $104 \mathrm{~d}$ (final). Further details are indicated in Fig. 2 legend.

VFI of fish was significantly increased when dietary protein was progressively substituted by $\mathrm{CH}$, confirming the strong dependency of this species on protein sources to display maximal growth ${ }^{(27)}$. However, the 48:38 dietary group showed the lowest values of DM, energy and protein retention, which indicates that the highest VFI presented in this group respond to 

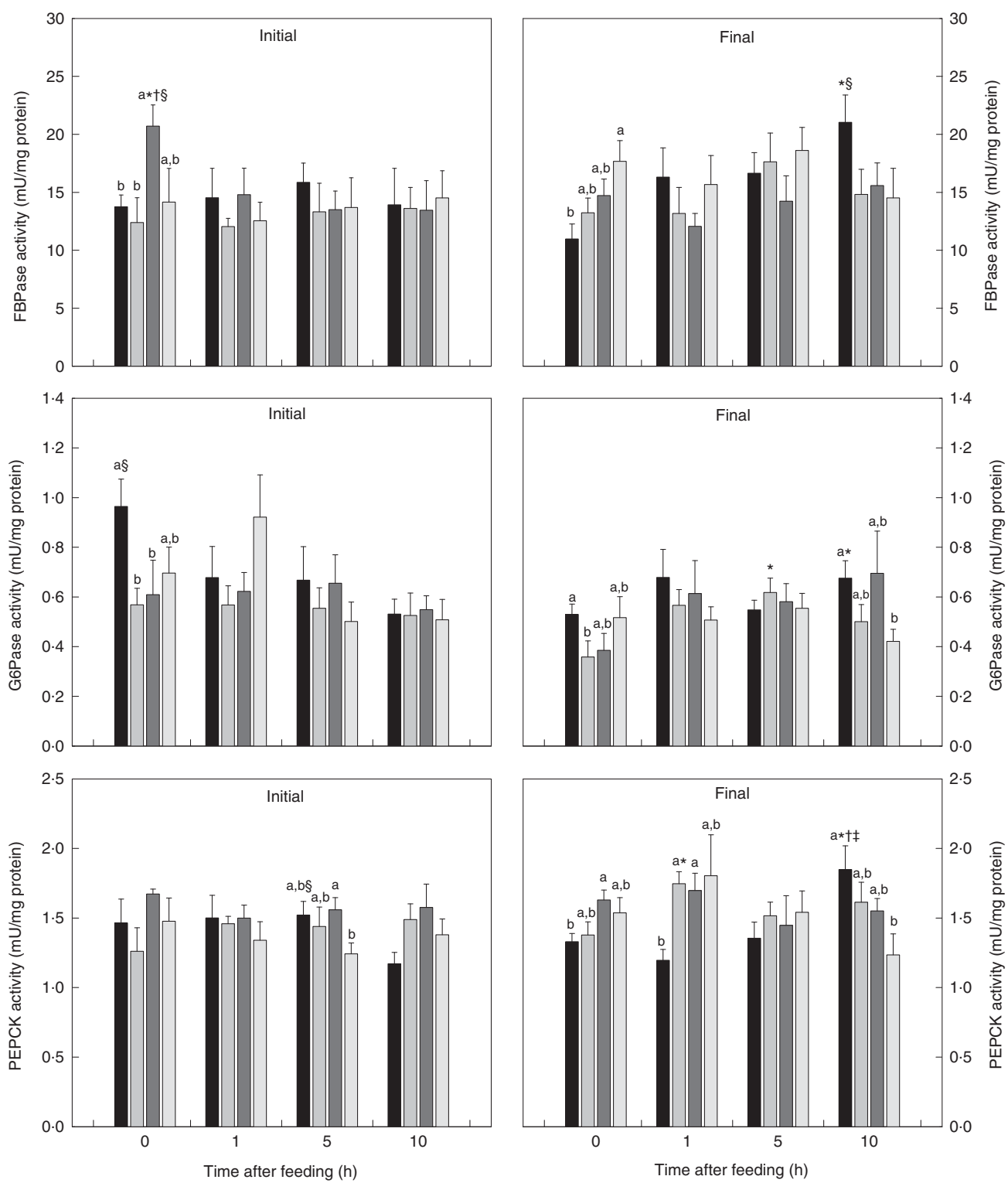

Fig. 5. Enzyme activity (mU/mg protein) related to glucoenogenesis in the liver. Fructose-1,6-biphosphatase (FBPase), glucose-6-phosphatase (G6Pase) and phosphoenolpyruvate carboxykinase (PEPCK) activity at different postprandial times (0,1,5 or 10 h) after feeding four experimental diets ( $\square$, 48:38; $\square, 52: 34$; $\square, 56: 30$ or $\square, 60: 26$ ) with different protein:carbohydarte ratios during $4 \mathrm{~d}$ (initial) or $104 \mathrm{~d}$ (final). Further details are indicated in Fig. 2 legend.

an essential protein requirement for energy purposes rather than for tissue accretion. No differences were found among the other dietary groups regarding nutrient and energy retention, suggesting that a protein: $\mathrm{CH}$ ratio of 52:34 is enough to induce maximal growth. The effect of the diets used in the present study on nutrient utilisation and flesh quality will be further discussed elsewhere (Salas-Leiton et al., unpublished results).

To see whether the use of diets with different contents of $\mathrm{CH}$ during an extended period could have some influence on glucose tolerance in Senegalese sole, GTT were performed at the initial ( 4 d) and final phases (104d) of the experiment. An oral GTT is commonly used to evaluate the capacity to restore glucose homoeostasis after an induced hyperglycaemia, and this has been carried out in many fish species ${ }^{(44)}$. The results are very divergent depending on the fish species, but, in general, omnivorous/herbivorous fish show better capacity to tolerate glucose than carnivorous species $^{(3)}$. In a previous study, Conde-Sieira et al. ${ }^{(31)}$ suggested that Senegalese sole, despite its carnivorous feeding habits, have a high capacity to deal with glucose loads and present fast glucose clearance rates comparable to those of omnivorous and/or herbivorous species. However, that study was carried out in fish fed a commercial diet (62\% crude protein, 16\% lipids and 9\% $\mathrm{CH}$ ) and did not allow predicting whether such a better glucose tolerance could be sustained in fish fed $\mathrm{CH}$-enriched diets over long-term periods. In the present study, the initial GTT was quite close to that observed before ${ }^{(31)}$, with glucose levels reaching the maximum $1 \mathrm{~h}$ after the glucose load, which again resembles the GTT described in omnivorous/herbivorous ${ }^{(2,45,46)}$ species rather than that reported in other carnivorous species ${ }^{(47,48)}$. 

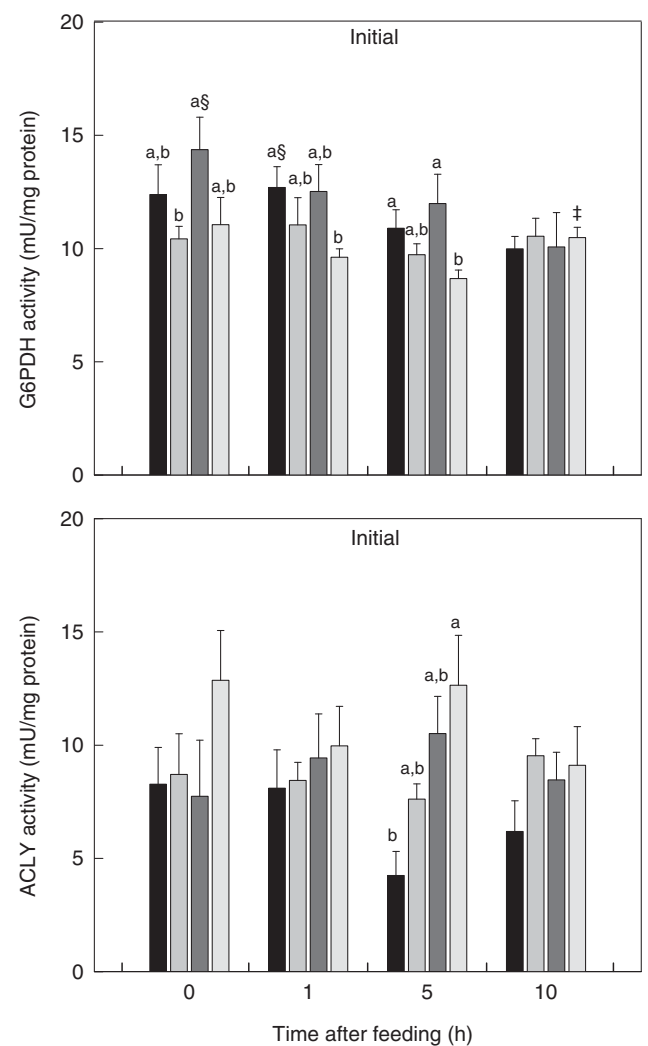
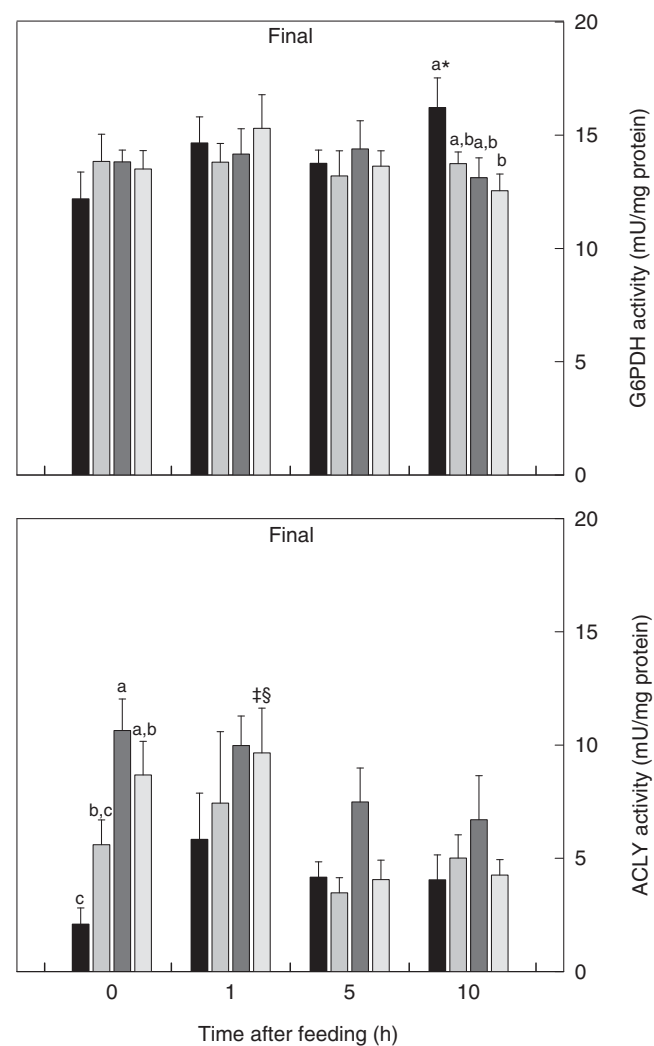

Fig. 6. Enzyme activity ( $\mathrm{mU} / \mathrm{mg}$ protein) related to lipogenesis in liver. Glucose-6-phosphate dehydrogenase (G6PDH) and ATP citrate lyase (ACLY) activity at different postprandial times $(0,1,5$ or $10 \mathrm{~h}$ ) after feeding four experimental diets $(\square, 48: 38 ; \square, 52: 34 ; \square, 56: 30$ or $\square, 60: 26$ ) with different protein:CH ratios during $4 \mathrm{~d}$ (initial) or $104 \mathrm{~d}$ (final). Further details are indicated in Fig. 2 legend.

In general, fish fed with the four experimental diets succeeded in returning glycaemia to normality in between 5 and $10 \mathrm{~h}$ post glucose load. These results suggest an effective capacity of Senegalese sole to deal with increased dietary $\mathrm{CH}$. If the initial GTT is compared with that observed at the end of the trial, two interesting observations arise: the first one is that glycaemia remained at high levels for a longer time period at the end of the trial, in a way that after $5 \mathrm{~h}$ of glucose load levels were basically the same as those observed $1 \mathrm{~h}$ after load, irrespectively of the dietary $\mathrm{CH}$ level; the second observation is that glycaemia in fish fed for $104 \mathrm{~d}$ with $\mathrm{CH}$-enriched diets was recovered $10 \mathrm{~h}$ after glucose load (except 60:26 diet) - that is, a time period perfectly comparable to that observed at the beginning of the trial. The experimental diets used in the present study are isolipidic and with low fat content $(6 \%)$, which indicates that differences in GTT presented in 60:26 can be related to the high protein or the low dietary $\mathrm{CH}$ content. In this way, the deleterious effect of a high-protein diet on glucose metabolism by promoting insulin resistance or impaired gluconeogenesis regulation has been reported in mammals and fish ${ }^{(49,50)}$. These changes in GTT suggest that Senegalese sole has an effective tolerance to the presence of increased amounts of $\mathrm{CH}$ in the diet, despite a slightly reduced ability to reduce glycaemia levels in a faster way after $104 \mathrm{~d}$ of feeding $\mathrm{CH}$-enriched diets.

The sustained glucose tolerance observed at the end of the trial is further supported by the results observed in plasma glucose levels after feeding experimental diets that, in general, were lower at the end than at the beginning of the trial. This is possible because of an improved metabolism in tissues that capture the circulating glucose more efficiently, therefore reducing glycaemia. As expected, plasma glucose values were higher in the fish fed $\mathrm{CH}$-enriched diets (48:38 and 52:34), except $5 \mathrm{~h}$ after feeding probably because at this time glucose is being used for metabolic purposes. However, plasma glucose level did not differ significantly from basal levels, which were higher than those previously observed in Senegalese sole ${ }^{(31)}$. The process of glucose clearance in plasma after feeding $\mathrm{CH}$ is slower than that registered in the GTT, and after $10 \mathrm{~h}$ fish fed the 52:34 diet still had a higher glycaemia than those fed the 60:26 diet. This is probably because of a more gradual influx of glucose to the bloodstream in accordance with the digestive processes. Furthermore, the partial effects of the presence of an increased amount of $\mathrm{CH}$ observed at the beginning of the trial (where plasma glucose levels are higher in $\mathrm{CH}$-enriched diets) basically disappeared at the end, further supporting the enhanced tolerance of $\mathrm{CH}$ in the diet that is not reflected in changes in glycaemia related to such $\mathrm{CH}$ dietary content. The higher levels of plasma glucose observed at the beginning of the experiment could be also a consequence of the nutritional background of the experimental fish, as they were previously fed a fattier diet (16\% lipids; $62 \%$ crude protein). In this sense, it has been reported in Senegalese sole that diets containing high level of lipids could impair glucose tolerance through the down-regulation of insulin signalling pathways ${ }^{(16)}$. 

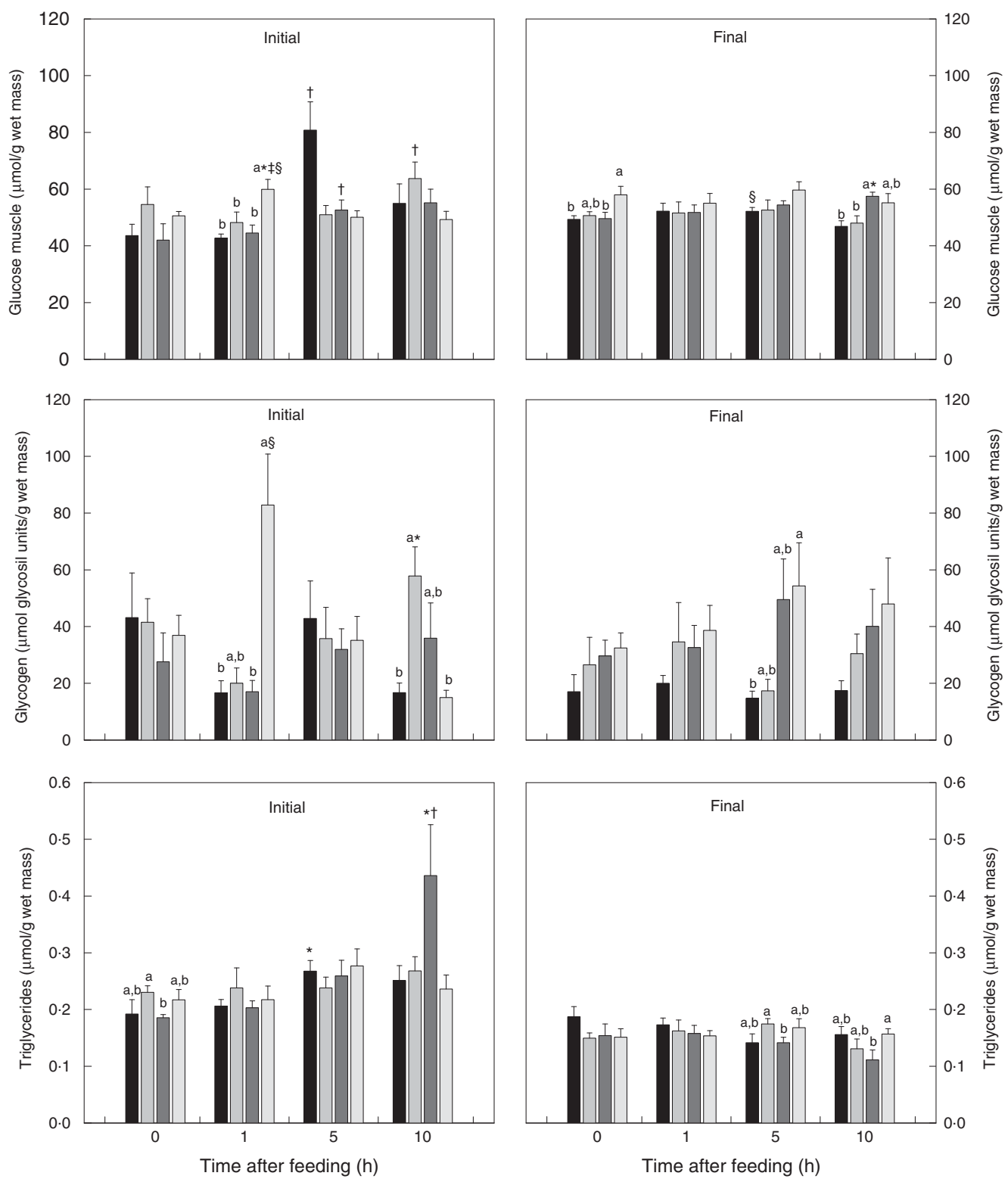

Fig. 7. Glucose, glycogen and trygliceride levels in muscle at different postprandial times $(0,1,5$ or $10 \mathrm{~h})$ after feeding four experimental diets $\square, 56: 30$ or $\square, 60: 26$ ) with different protein:carbohydrate ratio during $4 \mathrm{~d}$ (initial) or $104 \mathrm{~d}$ (final). Further details are indicated in Fig. 2 legend.

Liver has a key role in maintaining glucose homoeostasis in fish submitted to different nutritional conditions ${ }^{(17)}$. In the present study, the postprandial changes in hepatic levels of metabolites and enzyme activities related to pathways involved in glucose storage or production were evaluated in fish fed diets with different protein: $\mathrm{CH}$ contents. In general terms, glucose levels in liver did not differ among diets or time at the initial phase of the experiment, although a decrease in 56:30 diet was observed $5 \mathrm{~h}$ after feeding. Similarly, Conde-Sieira et al. ${ }^{(31)}$ have previously reported no significant changes in hepatic glucose levels in hyperglycaemic Senegalese sole after glucose administration, probably because of a fast removal of glucose in the liver.

The reasonable glucose tolerance displayed by Senegalese sole after $104 \mathrm{~d}$ of feeding $\mathrm{CH}$-enriched diets was also reflected in the levels of glycogen in liver, which were generally lower at the end than at the beginning of the trial. Moreover, the high glycogen levels induced by the high dietary $\mathrm{CH}$ content at the beginning of the trial disappeared at the end of the trial. Thus, it seems that Senegalese sole is able to deal with increasing amounts of dietary $\mathrm{CH}$ in an effective way, avoiding its excessive accumulation as glycogen. These results point towards an effective and fast glycogen metabolism in liver, reflecting a good adaptation of Senegalese sole to increased $\mathrm{CH}$ in the diet. This is supported by the increased activity of enzymes involved in glycogen metabolism (particularly GPase) at the end of the feeding period compared with the beginning of the trial.

The decrease of glucose levels in plasma at the end of the trial was not because of increased levels of glycogen in 

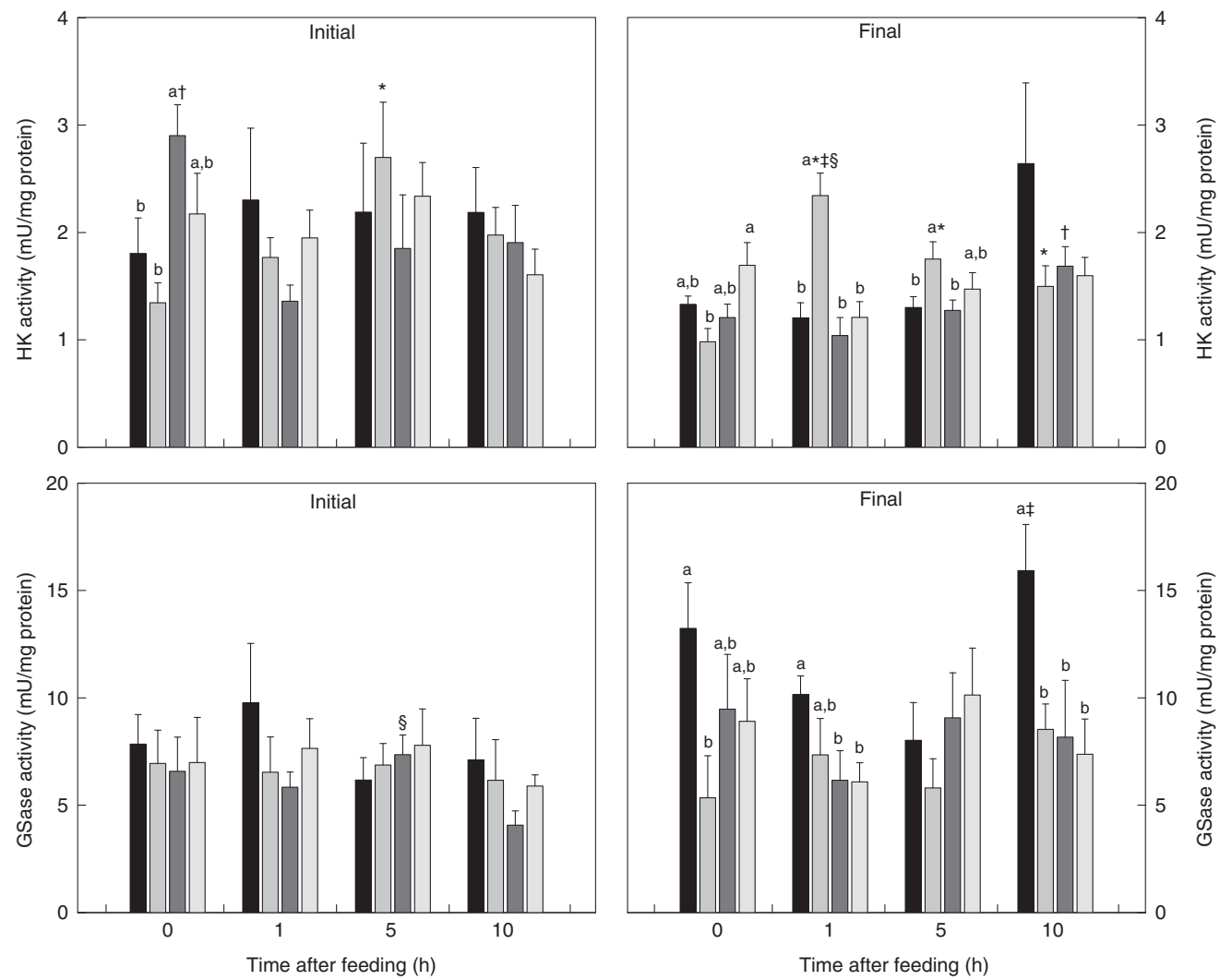

Fig. 8. Enzyme activity ( $\mathrm{mU} / \mathrm{mg}$ protein) of hexokinase $(\mathrm{HK})$ and glycogen synthase (GSase) in muscle at different postprandial times (0, 1,5 or $10 \mathrm{~h})$ after feeding four experimental diets ( $\square, 48: 38$; $\square, 52: 34$; $\square, 56: 30$ or $\square, 60: 26$ ) with different protein:carbohydrate ratios during 4 d (initial) or $104 \mathrm{~d}$ (final). Further details are indicated in Fig. 2 legend.

the liver pointing towards an effective use of glucose as fuel through the glycolytic pathway. GK is one of the main enzymes implicated in this pathway, and it has been reported to be nutritionally induced in many fish species $^{(17,32)}$ including Senegalese sole ${ }^{(31)}$. Accordingly, significant increments of GK activity were observed $10 \mathrm{~h}$ after feeding in all diets, with the exception of fish fed the lowest dietary $\mathrm{CH}$ content (60:26). This enhancement was of the same order of magnitude regardless of the dietary $\mathrm{CH}$ level (except 60:26), which may be because of a possible inhibition of GK expression when plasma glucose levels are elevated, as previously observed in rainbow trout $^{(51)}$. GK activities were in general higher at the end of the trial than at the beginning, suggesting a better capacity of phosphorylating glucose, which might explain the better postprandial glycaemic control observed at this stage. Similar results were previously reported in omnivorous (but not carnivorous) fish species ${ }^{(21)}$. However, PK, another enzyme involved in glycolisis, but whose activity is known to be poorly induced by nutritional conditions in fish ${ }^{(17)}$, was not correlated to dietary $\mathrm{CH}$ content. In fact, the diet with a higher $\mathrm{CH}$ level showed the lowest PK activity $10 \mathrm{~h}$ after feeding. The possible activation of the glycolytic capacity at the end of the trial might have coincided with an inhibition of the gluconeogenic potential resulting in a decreased liver capacity to export glucose into plasma. This capacity can indeed be assessed by changes in the activity of G6Pase, which showed a general decrease in the activity at the end of the trial $v$, the beginning. However, when the other two gluconeogenic enzymes (FBPase and PEPCK) were assessed, the expected inhibition was not observed. Previous studies in Senegalese sole also reported an inhibition of endogenous glucose production after glucose administration or, similar to the present study, after feeding high levels of $\mathrm{CH}^{(31,32)}$. These results reinforce the idea that Senegalese sole posses a good capacity to deal with glucose loads. However, the postprandial enzyme activities observed at the end of the experiment indicate no inhibition of gluconeogenesis. This lack of gluconeogenesis inhibition can be because of the influence of other macronutrients present in the diet, that is protein. There is increasing evidence that amino acids interfere with insulin function, affecting glucose homoeostasis by promoting insulin resistance and increasing gluconeogenesis ${ }^{(49)}$. Recent studies reported that high dietary $\mathrm{CH}$ per se are unable to inhibit G6Pase activity ${ }^{(14,17,19)}$, but dietary amino acids intake could also have a role and be a limiting factor for endogenous hepatic glucose production ${ }^{(20,50)}$.

The changes observed in lipid metabolism are indirectly related to the changes observed in glucose metabolism. If a fish is not able to effectively deal with increased levels of dietary $\mathrm{CH}$, this could result in increased deposition of lipids through up-regulation of de novo lipogenesis. In fact, many lipogenic enzymes were shown to be induced by a high-CH diet in 
mammals ${ }^{(52)}$. In fish fed $\mathrm{CH}$-enriched diets, an up-regulation of lipogenesis was observed in coho salmon ${ }^{(53)}$ but not in rainbow trout ${ }^{(23)}$. Postprandial stimulation of lipogenic enzymes, such as ACLY, was also observed in rainbow trout refed a high-protein diet $^{(54)}$. In Senegalese sole feeding diets with high $\mathrm{CH}$ and low lipid content also seems to promote hepatic lipogenesis ${ }^{(32,40)}$, although no changes in G6PDH activity were observed ${ }^{(31,32)}$. In the present study, and at the end of the trial, levels of NEFA in plasma were in general lower than those observed at the beginning of the trial. This suggests that $\mathrm{CH}$ are being effectively metabolised. In fact, in the liver, NEFA levels were also generally lower in fish at the end than at the beginning of the trial, suggesting a reduced lipogenic capacity that is further supported by the concomitant decrease in ACLY activity towards the end of the trial. Furthermore, in general, the higher the $\mathrm{CH}$ levels in the diet, the lower the ACLY activity, especially at the first postprandial hours. The absence of marked changes in liver lipogenic potential strengthens the important glucose tolerance of Senegalese sole, as the extra available glucose resulting from feeding $\mathrm{CH}$-enriched diets is used and not re-directed to synthesise lipid. However, considering that amino acids can be also used for lipogenesis, we cannot discard that the interchange of glucose with amino acids would explain the maintenance of lipogenesis in the liver.

The capacity of Senegalese sole to use $\mathrm{CH}$ as an energy source in the muscle is not as clear as in the liver. Non-carnivorous fish species have demonstrated a higher capacity to phosphorylate glucose in muscle compared with carnivorous ones ${ }^{(3,21)}$. However, dietary $\mathrm{CH}$ seem unable to induce significant changes in glucose metabolism in carnivorous fish muscle, which has been attributed to their glucose intolerance ${ }^{(1,23)}$. In the present study, a decreased capacity of muscle to use glucose through glycolysis was observed at the final phase of the experiment compared with the initial one. This could be related to the simultaneous enhanced use of glucose noted in liver and to the fact that this species is more tolerant to glucose than other carnivorous fish species. However, this not reflected in changes in glucose or glycogen levels in the muscle, although increased GSase activity was noted. TAG levels in muscle displayed lower levels at the final than at the initial phase of the experiment, which is in accordance with the lower lipogenic potential also observed in the liver. This could also be because of the lower lipid content of the experimental diets compared with those fed before the feeding trial, which are commonly used in commercial conditions ( $6 v .16 \%$ fat).

In summary, the results obtained in this study clearly suggest a good glucose tolerance in Senegalese sole and provide valuable information regarding the impact of feeding $\mathrm{CH}$-enriched diets for a long-term period on its metabolism. Senegalese sole tolerated important amounts of $\mathrm{CH}$ in the diet without showing any deleterious signs in terms of growth or any metabolic disorders. Moreover, the control of glycaemia was maintained after $104 \mathrm{~d}$ of feeding diets with an important amount of $\mathrm{CH}$, and, in general, postprandial glucose levels in plasma were even lower than at the beginning of the experiment. Importantly, fish metabolic response after $104 \mathrm{~d}$ of feeding was basically the same, irrespective of the dietary amounts of $\mathrm{CH}$ that were used. This indicates that the enzymatic machinery related to glucose metabolism was working efficiently in order to compensate the glucose load generated by $\mathrm{CH}$-enriched diets, reflecting a reasonable tolerance of Senegalese sole to such diets. This tolerance to glucose is also reflected by an increased use of glucose through glycolysis in liver, as well as by the non-necessity of increasing the lipogenic potential in the same tissue. In conclusion, the present results indicate that Senegalese sole seems to deal reasonably well with diets rich in $\mathrm{CH}$. However, this enhanced capacity to use $\mathrm{CH}$ implies a higher energy investment because of an elevated feeding activity in order to satisfy the high protein requirements of this species. Further studies where protein supply should be limited would help to clarify whether a protein-sparing effect of dietary $\mathrm{CH}$ is possible in Senegalese sole under a fixed ration of food supplied.

\section{Acknowledgements}

This work was partially supported by NORTE-07-0124-FEDER000038, in the context of the North Regional Operational Programme (ON.2 - O Novo Norte), under the project Sustainable Aquaculture and Animal Welfare (AQUAIMPROV) to L. M. P. V., and from Spanish Ministerio de Economía y Competitividad and European Fund for Regional Development (AGL2013-46448-3-1-R and FEDER) to J. L. S. M. C.-S. was recipient of a postdoctoral fellowship from Fundação para a Ciência e a Tecnologia (FCT) (SFRH/BPD/84251/2012) and from Xunta de Galicia (Plan I2C). E. S.-L. was partially covered by Andalusian Operational Program-European Social Fund (2007-2013), axis III.

M. C.-S., L. M. P. V. and J. L. S. conceived and designed the experiments; M. C.-S., E. S.-L. and N. F. P. performed the experiments; M. C.-S., E. S.-L., N. F. P. and M. M. D. analysed the data and M. C.-S., L. M. P. V. and J. L. S. wrote the paper.

There are no conflicts of interest in connection with the present study.

\section{Supplementary material}

For supplementary material/s referred to in this article, please visit http://dx.doi.org/doi:10.1017/S0007114516001057

\section{References}

1. Hemre GI, Mommsen TP \& Krogdahl A (2002) Carbohydrates in fish nutrition: effects on growth, glucose metabolism and hepatic enzymes. Aquac Nutr 8, 175-194.

2. Stone DAJ (2003) Dietary carbohydrate utilization by fish. Rev Fish Sci 11, 337-369.

3. Polakof S, Panserat S, Soengas JL, et al. (2012) Glucose metabolism in fish: a review. J Comp Physiol B 182, $1015-1045$.

4. Azaza MS, Khiari N, Dhraief MN, et al. (2013) Growth performance, oxidative stress indices and hepatic carbohydrate metabolic enzymes activities of juvenile Nile tilapia, Oreochromis niloticus L., in response to dietary starch to protein ratios. Aquac Res $\mathbf{4 6}, 14-27$.

5. Hamid NKA, Mahayat M \& Hashim R (2011) Utilization of different carbohydrate sources and starch forms by bagrid 
catfish (Mystus nemurus) (Cuv and Val). Aquac Nutr 17, e10-e18.

6. Enes P, Panserat S, Kaushik S, et al. (2011) Dietary carbohydrate utilization by European sea bass (Dicentrarchus labrax L.) and Gilthead sea bream (Sparus aurata L.) juveniles. Rev Fish Sci 19, 201-215.

7. Peres H \& Oliva-Teles A (2002) Utilization of raw and gelatinized starch by European sea bass (Dicentrarchus labrax) juveniles. Aquaculture 205, 287-299.

8. Mingchun R, Qinghui A, Kangsen M, et al. (2011) Effect of dietary carbohydrate level on growth performance, body composition, apparent digestibility coefficient and digestive enzyme activities of juvenile cobia, Rachycentron canadum L. Aquac Res 42, 1467-1475.

9. Piaoping Z, Mengqiang W, Fengjun X, et al. (2016) Effects of dietary carbohydrate to lipid ratios on growth performance, digestive enzyme and hepatic carbohydrate metabolic enzyme activities of large yellow croaker (Larmichthys crocea). Aquaculture 452, 45-51.

10. Aksnes A (1995) Growth, feed efficiency and slaughter quality of salmon, Salmo salar L., given feeds with different ratios of carbohydrate and protein. Aquac Nutr $\mathbf{1}$, 241-248.

11. Krogdahl A, Sundby A \& Olli JJ (2004) Atlantic salmon (Salmo salar) and rainbow trout (Oncorbynchus mykiss) digest and metabolize nutrient differently. Effects of water salinity and dietary starch level. Aquaculture 229, 335-360.

12. Panserat S, Medale F, Breque J, et al. (2000) Lack of significant long-term effect of dietary carbohydrates on hepatic glucose-6-phosphatase expression in rainbow trout (Oncorbynchus mykiss). J Nutr Biochem 11, 22-29.

13. Panserat S, Plagnes-Juan E, Breque J, et al. (2001) Hepatic phosphoenolpyruvate carboxykinase gene expression is not repressed by dietary carbohydrates in rainbow trout (Oncorbynchus mykiss). J Exp Biol 204, 359-365.

14. Panserat S, Capilla E, Gutierrez J, et al. (2001) Glucokinase is highly induced and glucose-6-phosphatase poorly repressed in liver of rainbow trout (Oncorbynchus mykiss) by a single meal with glucose. Comp Biochem Physiol B Biochem Mol Biol 128, 275-283.

15. Figueiredo-Silva AC, Panserat S, Kaushik S, et al. (2012) High levels of dietary fat impair glucose homeostasis in rainbow trout. $J$ Exp Biol 215, 169-178.

16. Borges P, Valente LMP, Véron V, et al. (2014) High dietary lipid level is associated with persistent hyperglycaemia and downregulation of muscle Akt-mTOR pathway in Senegalese sole (Solea senegalensis). PLOS ONE 9, e102196.

17. Enes P, Panserat S, Kaushik S, et al. (2009) Nutritional regulation of hepatic glucose metabolism in fish. Fish Physiol Biochem 35, 519-539.

18. Panserat S, Blin C, Medale F, et al. (2000) Molecular cloning, tissue distribution and sequence analysis of complete glucokinase cDNAs from gilthead seabream (Sparus aurata), rainbow trout (Oncorbynchus mykiss) and common carp (Cyprinus carpio). Biochim Biophys Acta 1474, 61-69.

19. Enes P, Panserat S, Kaushik S, et al. (2006) Rapid metabolic adaptation in European sea bass (Dicentrarchus labrax) juveniles fed different carbohydrate sources after heat shock stress. Comp Biochem Physiol A $\mathbf{1 4 5}$, 73-81.

20 Kirchner S, Seixas P, Kaushik S, et al. (2005) Effects of low protein intake on extra-hepatic gluconeogenic enzyme expression and peripheral glucose phosphorylation in rainbow trout (Oncorbynchus mykiss). Comp Biochem Physiol B Biochem Mol Biol 140, 333-340.
21. Capilla E, Medale F, Panserat S, et al. (2004) Response of hexokinase enzymes and the insulin system to dietary carbohydrates in the common carp, Cyprinus carpio. Reprod Nutr Dev 44, 233-242.

22. Panserat S, Plagnes-Juan E \& Kaushik S (2002) Gluconeogenic enzyme gene expression is decreased by dietary carbohydrates in common carp (Cyprinus carpio) and gilthead seabream (Sparus aurata). Biochim Biophys Acta 1579, 35-42.

23. Panserat S, Skiba-Cassy S, Seiliez I, et al. (2009) Metformin improves postprandial glucose homeostasis in rainbow trout fed dietary carbohydrates: a link with the induction of hepatic lipogenic capacities? Am J Physiol Regul Integr Comp Physiol 297, R707-R715.

24. Jin J, Medale F, Kamalam BS, et al. (2014) Comparison of glucose and lipid metabolic gene expressions between fat and lean lines of rainbow trout after a glucose load. PLOS ONE $\mathbf{9}$, e105548.

25. Geurden I, Aramendi M, Zambonino-Infante J, et al. (2007) Early feeding of carnivorous rainbow trout (Oncorbynchus mykiss) with a hyperglucidic diet during a short period: effect on dietary glucose utilization in juveniles. Am J Physiol Regul Integr Comp Physiol 292, R2275-R2283.

26. Morais S, Aragao C, Cabrita E, et al. (2014) New developments and biological insights into the farming of Solea senegalensis reinforcing its aquaculture potential. Rev Aquacult 6, 1-37.

27. Rema P, Conceição LEC, Evers F, et al. (2008) Optimal dietary protein levels in juvenile Senegalese sole (Solea senegalensis). Aquac Nutr 14, 263-269.

28. Borges P, Oliveira B, Casal S, et al. (2009) Dietary lipid level affects growth performance and nutrient utilisation of Senegalese sole (Solea senegalensis) juveniles. Br J Nutr 102, 1007-1014.

29. Borges P, Medale F, Dias J, et al. (2013) Protein utilisation and intermediary metabolism of Senegalese sole (Solea senegalensis) as a function of protein:lipid ratio. Br J Nutr $\mathbf{1 0 9}$, 1373-1381.

30. Borges P, Medale F, Veron V, et al. (2013) Lipid digestion, absorption and uptake in Solea senegalensis. Comp Biochem Physiol A Mol Integr Physiol 166, 26-35.

31. Conde-Sieira M, Soengas JL \& Valente LMP (2015) Potential capacity of Senegalese sole (Solea senegalensis) to use carbohydrates: metabolic responses to hypo- and hyperglycaemia. Aquaculture 438, 59-67.

32. Guerreiro I, Peres H, Castro C, et al. (2012) Water temperature does not affect protein sparing by dietary carbohydrate in Senegalese sole (Solea senegalensis) juveniles. Aquac Res $\mathbf{4 5}$, 289-298.

33. Association of Official Analytical Chemists (2006) Official Methods of Analysis of AOAC International. Gaithersburg, MD: AOAC International.

34. Thivend P, Mercier C \& Guilbot A (1972) Determination of starch with glucoamylase. In Methods in Carbohydrate Chemistry, pp. 100-105 [RL Whistler and JN Bemiller, editors]. New York, NY: Academic Press.

35. Cabral EM, Fernandes TJR, Campos SD, et al. (2013) Replacement of fishmeal by plant protein sources up to $75 \%$ induces good growth performance without affecting flesh quality in ongrowing Senegalese sole. Aquaculture 380-383, 130-138.

36. Polakof S, Míguez JM \& Soengas JL (2008) Dietary carbohydrates induce changes in glucosensing capacity and food intake of rainbow trout. Am J Physiol Regul Integr Comp Physiol 295, 478-489.

37. Keppler D \& Decker K (1974) Glycogen determination with amyloglucosidase. In Methods of Enzymatic Analysis, pp. 1127-1131 [HU Bergmeyer, editor]. New York, NY: Academic Press. 
38. Smith PK, Krohn RI, Hermanson GT, et al. (1985) Measurement of protein using bicinchoninic acid. Anal Biochem 150, 76-85.

39. Cabral EM, Bacelar M, Batista S, et al. (2011) Replacement of fishmeal by increasing levels of plant protein blends in diets for Senegalese sole (Solea senegalensis) juveniles. Aquaculture 322-323, 74-81.

40. Dias J, Rueda-Jasso R, Panserat S, et al. (2004) Effect of dietary carbohydrate-to-lipid ratios on growth, lipid deposition and metabolic hepatic enzymes in juvenile Senegalese sole (Solea senegalensis, Kaup). Aquac Res 35, 1122-1130.

41. Hillestad M, Johnsen F \& Åsgård T (2001) Protein to carbohydrate ratio in high-energy diets for Atlantic salmon (Salmo salar L.). Aquac Res 32, 517-529.

42. Viaplana-Marín I, Fernández-Borrás J \& Blasco J (2006) Effects of the protein/carbohydrate ratio of extruded diets on protein synthesis, protein growth and body composition in juveniles brown trout (Salmo trutta). Aquac Int 14, 337-353.

43. Rawles SD, Smith SB \& Gatlin DM (2008) Hepatic glucose utilization and lipogenesis of hybrid striped bass (Morone chrysops $\times$ Morone saxatilis) in response to dietary carbohydrate level and complexity. Aquac Nutr 14, 40-50.

44. Moon TW (2001) Glucose intolerance in teleost fish: fact or fiction? Comp Biochem Physiol B Biochem Mol Biol 129, 243-249.

45. Furuichi M \& Yone Y (1981) The utilization of carbohydrate by fishes. Change of blood sugar and plasma insulin levels of fishes in glucose tolerance test. Bull Jpn Soc Sci Fish 47, 761-764.
46. Lin JH, Ho LT \& Shiau SY (1995) Plasma glucose and insulin concentration in tilapia after oral administration of glucose and starch. Fish Sci 61, 986-988.

47. Garcia-Riera MP \& Hemre GI (1996) ) Glucose tolerance in turbot, Scophthalmus maximus (L.). Aquac Nutr 2, 117-120.

48. Hemre GI, Torrissen O, Krogdahl A, et al. (1995) Glucose tolerance in Atlantic salmon, Salmo salar L., dependence on adaptation to dietary starch and water temperature. Aquac Nutr 1, 69-75.

49. Tremblay F, Lavigne C, Jacques H, et al. (2007) Role of dietary proteins and amino acids in the pathogenesis of insulin resistance. Annu Rev Nutr 27, 293-310.

50. Kirchner S, Kaushik S \& Panserat S (2003) Low protein intake is associated with reduced hepatic gluconeogenic enzyme expression in rainbow trout (Oncorbynchus mykiss). J Nutr 133, 2561-2564.

51. Skiba-Cassy S, Panserat S, Larquier M, et al. (2013) Apparent low ability of liver and muscle to adapt to variation of dietary carbohydrate:protein ratio in rainbow trout (Oncorbynchus mykiss). Br J Nutr 109, 1359-1372.

52. Towle HC, Kaytor EN \& Shih HM (1997) Regulation of the expression of lipogenic enzyme genes by carbohydrate. Annu Rev Nutr 17, 405-433.

53. Lin H, Romsos DR, Tack PI, et al. (1977) Influence of diet on in vitro and in vivo rates of fatty acid synthesis in coho salmon [Oncorbynchus kisutch (Walbaum)]. J Nutr 107, 1677-1682.

54. Seiliez I, Panserat S, Lansard M, et al. (2011) Dietary carbohydrate-to-protein ratio affects TOR signaling and metabolism-related gene expression in the liver and muscle of rainbow trout after a single meal. Am J Physiol Regul Integr Comp Physiol 300, R733-R743. 